\title{
Koordinasi Publik untuk Pengurangan Risiko Bencana (PRB) Banjir pada Pelaksanaan Pembangunan Berkelanjutan Gorontalo
}

\author{
Ivan Taslim ${ }^{1}$ \\ Universitas Muhammadiyah Gorontalo, Gorontalo, Indonesia \\ Muh. Firyal Akbar \\ Universitas Muhammadiyah Gorontalo, Gorontalo, Indonesia
}

Artikel Masuk : 27 Oktober 2018

Artikel Diterima : 27 Juni 2019

Tersedia Online : 31 Agustus 2019

\begin{abstract}
Abstrak: Pada wilayah rawan banjir, koordinasi antarpihak dalam kegiatan pengurangan risiko bencana sangat penting dilaksanakan. Hal ini dikarenakan bencana secara langsung akan berdampak pada gangguan kehidupan dan penghidupan masyarakat, juga menghambat proses pembangunan berkelanjutan. Penelitian ini bertujuan untuk menyusun skema koordinasi publik untuk kegiatan pengurangan risiko bencana (PRB) banjir berbasis sumber daya publik yang tersedia di Kabupaten Gorontalo. Sumber daya publik berasal dari instansi pemerintah dan potensi masyarakat yang tersedia di Kabupaten Gorontalo dengan tugas masing-masing pada tahap sebelum, saat dan setelah bencana. Koordinasi publik diharapkan dapat mendukung pelaksanaan pembangunan berkelanjutan yang berbasis PRB di Kabupaten Gorontalo. Penyusunan skema koordinasi publik didahului penilaian bahaya banjir secara geospasial berdasarkan karakteristik Daerah Aliran Sungai (DAS) Limboto menggunakan perangkat Sistem Informasi Geografis (SIG). Hasil penilaian tersebut menjadi dasar pelaksanaan penyusunan koordinasi publik untuk PRB. Kabupaten Gorontalo didominasi oleh satuan lahan pesisir yang berbatasan dengan Teluk Tomini, dataran hingga pegunungan. Curah hujan tinggi, tata guna lahan yang kritis serta permukiman yang berada di dataran rendah menyebabkan daerah penelitian termasuk pada zona risiko tinggi hingga sangat tinggi mengalami banjir. Pembangunan berkelanjutan dapat berjalan efektif apabila pelaksanaannya berbasiskan kebijakan PRB dengan koordinasi publik. Koordinasi publik dilakukan di antara instansi pemerintah dan masyarakat, yang bekerja sama sesuai peran dan tugas masingmasing pada tahap sebelum, saat hingga setelah bencana. Hasil penelitian menunjukkan bahwa dibutuhkan keterlibatan sektor yang lebih banyak pada tahap sebelum dan saat bencana. Hal ini mengindikasikan bahwa koordinasi publik sebelum terjadinya bencana merupakan kegiatan pencegahan dan pengurangan risiko yang harusnya lebih diutamakan dalam pelaksanaan pembangunan sebelum menghambat keberlanjutan pembangunan.
\end{abstract}

Kata Kunci: banjir; koordinasi publik; pembangunan berkelanjutan; pengurangan risiko; SIG

Abstract: In flood-prone areas, coordination between parties in disaster risk reduction (DRR) activities is very important. This is because the consequences of disasters will directly affect

\footnotetext{
${ }^{1}$ Korespondensi Penulis: Universitas Muhammadiyah Gorontalo, Gorontalo, Indonesia

Email: ivantaslim@umgo.ac.id
} 


\section{Koordinasi Publik untuk Pengurangan Risiko Bencana Banjir ...}

the disruption of people's lives and livelihoods, and also hinder the process of sustainable development. The study aims to develop a public coordinating scheme for disaster risk reduction (DRR) activities based on public resources in Gorontalo Regency. Public resources from government agencies and society are available in Gorontalo Regency with their respective tasks at the stages before, during and after the disaster. Public coordination is expected to support the implementation of DRR-based sustainable development in Gorontalo Regency. The preparation of public coordination scheme begins with geospatial flood hazard assessment based on the characteristics of the Limboto Watershed using a Geographic Information System (GIS) tool. The result provides a basis for the implementation of public coordination arrangements for DRR. Gorontalo Regency is dominated by a coastal land parcel adjacent to Tomini Bay, stretching from lowland plains to hilly mountains. High rainfall, critical land use and settlements in the lowlands have caused the study area categorized into high- to very high-risk zones of flooding. To ensure sustainable development runs effectively, its implementation must be based on DRR policy with public coordination. Public coordination is carried out between government agencies and society, who cooperate in compliance with their respective roles and tasks at the stage before, during and after the disaster. The results show that the involvement of more sectoral parties is needed at the stage before and during the disaster. This indicates that public coordination before the disaster performs risk prevention and reduction activity that should be prioritized in the implementation of development before inhibiting its sustainability.

Keywords: floods; GIS; public coordination; risk reduction; sustainable development

\section{Pendahuluan}

Indonesia merupakan negara dengan tingkat kerawanan bencana alam tinggi. Letaknya yang berada pada pertemuan lempeng aktif dunia dapat menyebabkan bencana geologi. Selain itu, secara astronomis Indonesia berada pada zona garis khatulistiwa yang beriklim tropis dengan risiko bencana hidrometeorologi. Hal ini menjadi sebuah indikasi bahwa dalam rencana pengembangan wilayah, pemerintah seharusnya tidak berdasar pada kebutuhan pembangunan saja, tetapi juga perlu mempertimbangkan aspek bahaya bencana yang dapat menghambat pembangunan berkelanjutan di negara ini (Taslim, Koto, dan Tisen, 2017). Untuk mencapai tujuan pembangunan berkelanjutan di Indonesia, sesuai yang diamanatkan Perserikatan Bangsa-Bangsa (PBB) melalui dokumen Transforming Our World: The 2030 Agenda for Sustainable Development, Pemerintah Indonesia telah mengadopsi tujuh belas tujuan pembangunan berkelanjutan dengan 169 sasaran (United Nations, 2015b). Hal ini juga telah diatur melalui Peraturan Presiden (Perpres) No. 2 Tahun 2015 tentang Rencana Pembangunan Jangka Menengah Nasional (RPJMN) 2015-2019, dan pada pelaksanaannya dijabarkan melalui Perpres No. 59 Tahun 2017 tentang Pelaksanaan Pencapaian Tujuan Pembangunan Berkelanjutan 2016-2030. Dalam kebijakan tersebut telah diuraikan sektor/instansi pemerintah yang bertanggung jawab terhadap pelaksanaannya.

Konsep pembangunan yang berkelanjutan sebenarnya sudah diatur dalam UndangUndang Republik Indonesia (UU) No. 26 Tahun 2007 tentang Penataan Ruang. Hal ini tentu harus disertai dengan pengetahuan, selain data dan informasi mengenai kebencanaan oleh masyarakat dan pemerintah sebagai pemegang kebijakan dalam penyelenggaraan pembangunan. Pemerintah dan masyarakat yang merupakan satu bagian dari sebuah komunitas, tentu harus saling terkait, berkoordinasi dan bekerja sama dalam mewujudkan pembangunan yang berkelanjutan. UU No. 24 Tahun 2007 tentang Penanggulangan Bencana memberikan mandat kepada Badan Nasional Penanggulangan Bencana (BNPB) dan Badan Penanggulangan Bencana Daerah (BPBD) sebagai koordinator, komando dan pelaksana dalam penanggulangan bencana. 
Penanggulangan bencana bersifat multisektoral, multistakeholder, dan multibahaya, sehingga kunci suksesnya adalah koordinasi dan komando (Ahdi, 2015). Namun, koordinasi terkadang memiliki masalah yang kompleks dan tidak mudah untuk diselesaikan oleh satu sektor saja, sehingga kemitraan dan kolaborasi (interoperabilitas) mutlak diperlukan untuk memastikan penanganan atau respon yang tepat dalam penanggulangan bencana (Anam, Mutholib, Setiyawan, Andini, dan Sefniwati, 2018). Penanggulangan bencana yang baik juga harus mempersiapkan tidak hanya untuk fase kedaruratan saja, tetapi juga mempersiapkan kerangka yang baik pada fase sebelum dan sesudah bencana (Yumantoko, 2019). Dengan adanya penanggulangan bencana yang baik dan terkoordinasi, maka akan jelas sektor-sektor yang perlu terlibat, apa yang dapat dilakukan dan bagaimana mekanisme kerjanya. Kerangka koordinasi dalam penanggulangan bencana ini tentu harus dimiliki oleh setiap wilayah di Indonesia, termasuk Kabupaten Gorontalo.

Kabupaten Gorontalo merupakan salah satu wilayah administratif di Provinsi Gorontalo yang terbentuk berdasarkan UU No. 38 Tahun 2000 tentang Pembentukan Provinsi Gorontalo, dan saat ini sedang menggiatkan pembangunan berkelanjutan di semua sektor. Selama tahun 2000-2018, wilayah ini telah mengalami bencana banjir sebanyak 44 kali (BNPB, 2018). Salah satu bencana banjir paling parah terjadi pada tahun 2016. Banjir merendam hingga sembilan daerah kecamatan, termasuk Kota Limboto yang merupakan ibukota kabupaten, dengan dampak beberapa infrastruktur fasilitas umum mengalami kerusakan dan ribuan orang mengungsi (Azhar, 2016). Kejadian banjir yang sering terjadi merupakan akibat meluapnya sungai-sungai pada Sub-DAS Biyonga, Bulota dan Alo yang termasuk dalam DAS Limboto. Sekitar 20,95\% area dari salah satu sub-DAS tersebut telah mengalami degradasi lahan akibat pembangunan yang tidak sesuai dengan arahan fungsi kawasan berdasarkan Surat Keputusan (SK) Menteri Pertanian No. 837/Kpts/Um/11/1980 tentang Kriteria dan Tata Cara Penetapan Hutan Lindung (Ake, Koto, dan Taslim, 2018). Hal ini menandakan bahwa ada perencanaan tata ruang wilayah yang tidak memperhatikan arahan kebijakan yang ada, sementara kebijakan itu sendiri telah melalui kajian akademik risiko bencana. Selain itu, adanya perubahan tata guna lahan oleh masyarakat di daerah sub-DAS yang tidak sesuai dengan fungsinya, memperlihatkan bahwa kurangnya peran pemerintah dalam sosialisasi edukasi mengenai pentingnya kesesuaian lahan untuk mengurangi risiko terjadinya bencana di masa depan.

Pembangunan yang direncanakan pemerintah daerah sudah seharusnya menggunakan kebijakan pembangunan tidak hanya berdasarkan kajian kebutuhan saja, tetapi juga mengkaji dampak setelah maupun keberlanjutan pembangunan tersebut (Wibowo, 2018). Dalam hal ini, kemampuan pemerintah daerah dalam manajemen risiko bencana merupakan hal yang sangat penting dalam pembangunan berkelanjutan (Probosiwi, 2015). Pemerintah daerah belum memiliki kesadaran yang memadai untuk mengarusutamakan pengurangan risiko bencana dalam kebijakan perencanaan pembangunan, karena masih menganggap bahwa penanggulangan bencana hanya dilakukan untuk respon kedaruratan saja (Hidayah, 2015). Kejadian bencana banjir yang seringkali terjadi di Kabupaten Gorontalo tentu telah menghambat dan memperlambat penyelenggaraan pembangunan. Hal terpenting dari perencanaan wilayah tidak hanya mengharuskan pengambil kebijakan memiliki informasi risiko bencana, tetapi juga mengetahui tentang faktor-faktor penyebab terjadinya, bagaimana cara mengurangi dampak dari risikonya, serta usaha apa yang harus dilakukan untuk mengantisipasinya sebagai manajemen pembangunan dalam jangka waktu dekat dan keberlanjutannya di masa akan datang. Dalam penanggulangan bencana diperlukan sebuah koordinasi berbasis sumber daya publik yaitu adanya saling kerja sama antarlembaga atau instansi pemerintah, akademisi serta masyarakat sesuai peran dan tugas masing-masing (Faturahman, 2018). Oleh karena itu, pelaksanaan pembangunan berkelanjutan di Kabupaten Gorontalo membutuhkan sebuah perencanaan yang mengadaptasi koordinasi penyelenggaraan 
pengurangan risiko bencana dengan berbasis sumber daya publik yang tersedia. Dampak bencana banjir dalam 10 tahun terakhir sampai dengan April 2018 telah mengakibatkan tujuh orang meninggal dan sekitar 4.151 jiwa mengungsi serta menyebabkan kerusakan dan kerugian terhadap rumah, fasilitas umum dan lahan (BNPB, 2018). Kerusakan dan kerugian akibat peristiwa banjir tersebut menjadi salah satu indikasi bahwa bencana telah menghambat keberlanjutan pembangunan di Kabupaten Gorontalo. Tujuan Pembangunan Berkelanjutan (TPB) yang terhambat akibat bencana banjir tersebut antara lain: (1) adanya kerusakan rumah-rumah masyarakat maupun lahan pertanian yang menimbulkan kerugian harta dan benda dalam jumlah yang besar, sehingga menghambat TPB ke-1 yaitu pengentasan kemiskinan (no poverty); (2) sekitar 4.112 Ha lahan sawah dan $14.000 \mathrm{Ha}$ areal hutan terdampak bencana banjir, sehingga menghambat TPB ke-2 yaitu meniadakan kelaparan (zero hunger); (3) fasilitas umum yang ikut terdampak di antaranya fasilitas kesehatan dan pendidikan sehingga menghambat TPB ke-3 yaitu kesehatan dan kesejahteraan yang baik (good health and well being) dan ke-4 yaitu pendidikan berkualitas (quality education); (4) peristiwa banjir yang terjadi memiliki dampak lanjutan yaitu sulit atau kurangnya akses mendapatkan air bersih dan sanitasi sehingga hal ini menghambat TPB ke-6 yaitu air bersih dan sanitasi (clean water and sanitation); (5) kerusakan beberapa sarana transportasi jalan dan jembatan hingga tempat usaha (pabrik, kios, dan sebagainya) juga menyebabkan keterhambatan pertumbuhan ekonomi dan lapangan usaha atau tepatnya TPB ke-8 yaitu pekerjaan yang layak dan pertumbuhan ekonomi (decent work and economic growth); (6) tidak bertumbuhnya ekonomi suatu daerah akibat bencana secara langsung akan menghambat pembangunan yang juga merupakan TPB ke-11 yaitu kota dan masyarakat yang berkelanjutan (sustainable cities and communities); dan (7) bencana banjir merupakan peristiwa terganggunya kehidupan dan penghidupan masyarakat daerah yang terdampak, dan akibat dari hal ini adalah terhambatnya TPB ke-15 yaitu kehidupan di atas bumi (life on land).

Penelitian ini bertujuan untuk menyusun menyusun skema koordinasi publik untuk kegiatan pengurangan risiko bencana (PRB) banjir berbasis sumber daya publik yang tersedia di Kabupaten Gorontalo. Skema ini diharapkan akan menginisiasi terbitnya sebuah dokumen Pengurangan Risiko Bencana Berbasis Koordinasi Publik oleh Pemerintah Kabupaten Gorontalo, yang disusun berdasarkan tahap pra bencana, saat bencana dan pasca bencana beserta organisasi perangkat daerah (OPD) dan potensi masyarakat yang terlibat untuk saling berkoordinasi secara lintas sektor, dengan menyesuaikan peran dan fungsi masing-masing dalam PRB banjir di Kabupaten Gorontalo.

\section{Metode Penelitian}

Dalam mendukung penyelenggaraan pembangunan berkelanjutan di Kabupaten Gorontalo, perlu adanya penyusunan skema rencana koordinasi yang terukur dan spesifik, dan dilakukan sebelum, pada saat hingga setelah kondisi darurat bencana terjadi di suatu wilayah. Penyusunan skema atau rencana koordinasi publik tersebut dibuat dalam rangka mengurangi risiko bencana berdasarkan hasil analisis ancaman atau risiko bahaya yang diperkirakan akan terjadi ataupun belum tentu terjadi. Pada wilayah penelitian yang seringkali mengalami bencana banjir, skema koordinasi publik dibuat berdasarkan informasi risiko banjir yang didapatkan atas penilaian bahaya secara geospasial (geospatial hazard assessment/GHA) (Dewan, 2013), dan karakteristik DAS Limboto beserta rata-rata curah hujan selama 10 tahun (2008-2018). Selain itu, dilakukan pula inventarisasi sumber daya publik yang tersedia, di antaranya dari instansi pemerintah dan potensi masyarakat (Vidiarina, 2010). Selanjutnya dalam skema koordinasi publik yang dibuat sudah dijelaskan tugas dan fungsi yang akan dilakukan oleh masing-masing komunitas dalam PRB banjir tersebut. Adapun wilayah penelitian yang dinilai risiko bahayanya adalah DAS Limboto, 
mencakup Kecamatan Limboto dan Kecamatan Limboto Barat, yang merupakan pusat pemerintahan Kabupaten Gorontalo, sebagaimana dapat dilihat pada Gambar 1.

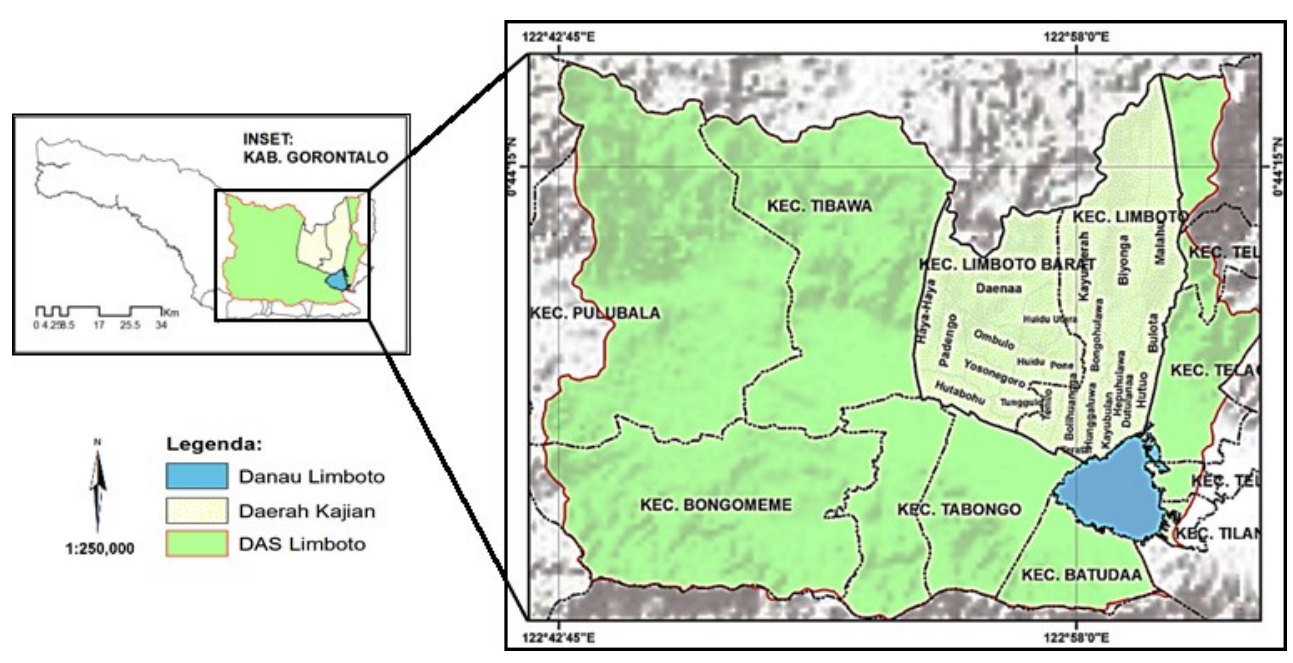

Sumber: Pemerintah Kabupaten Gorontalo, 2013 (modifikasi)

\section{Gambar 1. Daerah Aliran Sungai Limboto}

Metode analisis yang dilakukan dalam penelitian ini meliputi studi literatur, GHA, dan penyusunan skema koordinasi publik. Studi literatur dan pengumpulan data dan informasi mengenai karakteristik wilayah kajian berupa peta tematik jenis tanah, kemiringan lereng, tipe morfologi dan topografi, tata guna lahan hingga rerata curah hujan tahunan, serta inventarisasi sumber daya publik yang tersedia yang dalam hal ini instansi pemerintah dan potensi masyarakat seperti institusi pendidikan, lembaga nonpemerintah dan internasional, swasta hingga media yang akan saling berkoordinasi dalam PRB banjir di Kabupaten Gorontalo. GHA dilakukan untuk menilai bahaya banjir pada wilayah kajian secara geospasial. GHA merupakan pemrosesan data peta tematik menurut parameter karakteristik wilayah kajian di DAS Limboto dengan teknik skoring (scoring) dan tumpang susun (overlay) memanfaatkan perangkat lunak SIG. Tahap ini merupakan tahap awal yang harus dilakukan sebagai dasar penyusunan skema koordinasi publik untuk PRB banjir, yaitu dengan menentukan zona risiko terlebih dahulu. Penyusunan skema koordinasi publik menurut tugas dan fungsi masing-masing seperti menurut Vidiarina (2010) dengan modifikasi nama instansi yang tersedia untuk PRB banjir, mulai dari tahap pra bencana, saat terjadi bencana hingga pasca bencana. Kerangka tahap penelitian dapat dilihat pada Gambar 2.

\section{Hasil dan Pembahasan}

\section{Pelaksanaan Pembangunan Berkelanjutan}

Pembangunan yang berkelanjutan seharusnya juga tanggap dan tangguh akan bencana. Untuk itu penataan ruang diselenggarakan dengan memperhatikan kondisi fisik wilayah yang rentan terhadap bencana sesuai pertimbangan UU No. 26 Tahun 2007 tentang Penataan Ruang, bahwa secara geografis Negara Kesatuan Republik Indonesia (NKRI) berada pada kawasan rawan bencana sehingga diperlukan penataan ruang yang berbasis mitigasi bencana sebagai upaya meningkatkan keselamatan dan kenyamanan 
kehidupan dan penghidupan. Tatanan geologi Indonesia terletak di antara pertumbukan tiga buah lempeng, yaitu Lempeng Eurasia, Lempeng Asia dan Lempeng Australia yang sangat aktif hingga menjadikan negara ini sangat berpotensi mengalami bencana geologi seperti gempa bumi, gunung meletus serta tsunami (Idris dan Pramudito, 2018). Secara astronomis Indonesia dilewati oleh garis khatulistiwa dengan iklim tropis yang memiliki dua musim, yaitu hujan dan kemarau, yang berpotensi menyebabkan bencana hidrometeorologi di antaranya banjir, longsor kekeringan dan kebakaran hutan dan lahan (Suryani, 2016). Kondisi ekosistem alamiah Indonesia juga sangat khas karena berada di dekat khatulistiwa dengan cuaca, musim, dan iklim tropis, merupakan aset atau sumber daya yang sangat besar bagi bangsa Indonesia. Di samping keberadaan yang bernilai sangat strategis tersebut, Indonesia berada pula pada kawasan rawan bencana, yang secara alamiah dapat mengancam keselamatan bangsa (Eddy, 2015).

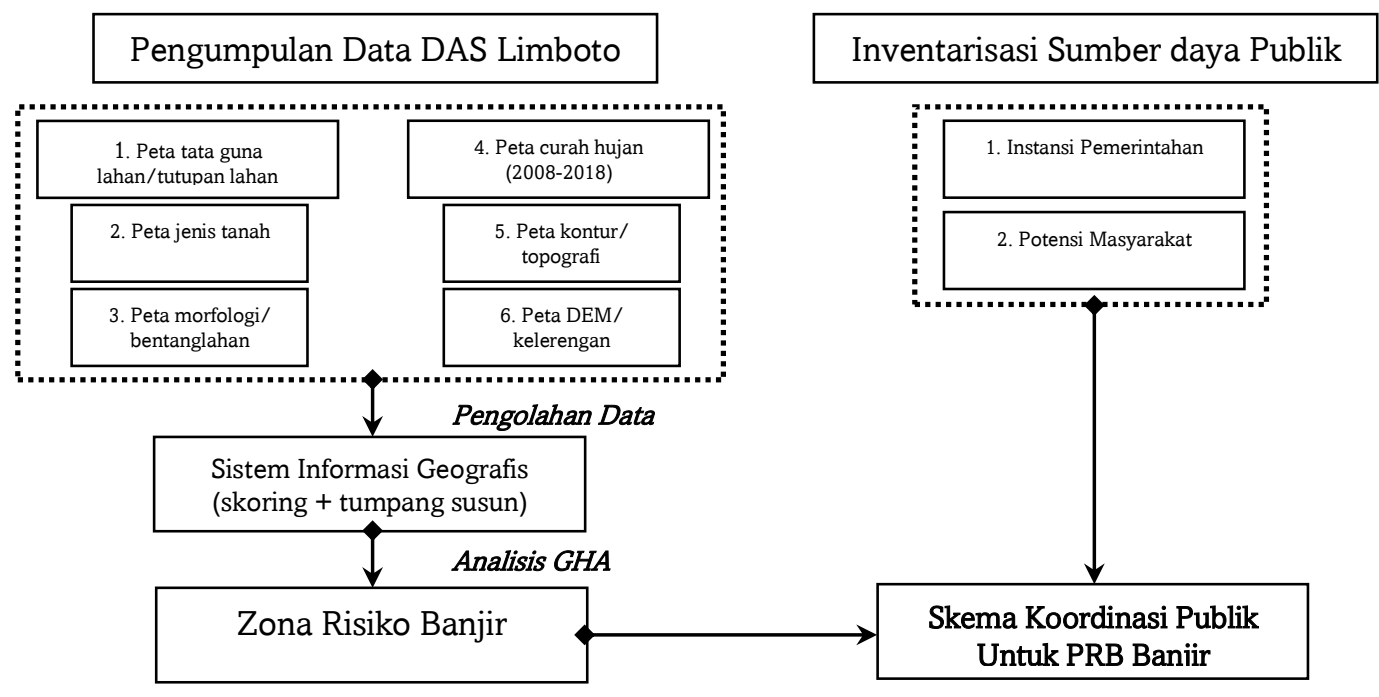

Gambar 2. Kerangka Tahap Penelitian

UU No. 23 Tahun 2014 tentang Pemerintahan Daerah, UU No. 33 Tahun 2004 tentang Perimbangan Keuangan Antara Pemerintah Pusat dan Pemerintah Daerah, serta Peraturan Pemerintah (PP) No. 25 Tahun 2000 tentang Kewenangan Pemerintah dan Kewenangan Propinsi Sebagai Daerah Otonom memberikan kewenangan yang sangat besar kepada pemerintah kota dan kabupaten untuk mengelola pembangunan daerahnya, khususnya dalam administrasi pemerintahan dan keuangan. Oleh karena itu, saat ini pemerintah kota/kabupaten mempunyai peran dan fungsi yang sangat strategis dalam rangka melaksanakan pembangunan di segala bidang, yang bertujuan meningkatkan peran kota/kabupaten sebagai pusat pertumbuhan wilayah, penggerak pembangunan, pusat jasa pelayanan dalam segala bidang, serta pusat informasi dan inovasi, termasuk dalam hal teknologi mitigasi bencana (Bakornas PBP, 2002). Berkaitan dengan penjelasan peraturan tentang penataan ruang di Indonesia tersebut, maka setiap daerah juga harus mempunyai rencana dan aturannya sendiri dalam mewujudkan pembangunan yang berkelanjutan.

Pemerintah Kabupaten Gorontalo telah mengatur hal-hal yang berkaitan dengan pembangunan berkelanjutan daerahnya agar tangguh bencana melalui Peraturan Daerah (Perda) Kabupaten Gorontalo No. 4 Tahun 2013 tentang Rencana Tata Ruang Wilayah (RTRW) Kabupaten Gorontalo Tahun 2012-2032. Hal ini mengingat bahwa Kabupaten Gorontalo secara umum memiliki kondisi geologi yang didominasi oleh berbagai jenis litologi mulai dari batuan gunung api pinogu (TQpv), batuan gunung api bilungala (Tmbv), 
lalu endapan danau (Qpl), batu gamping klastika (TQl) dan batu gamping terumbu (Ql) (Apandi dan Bachri, 1997). Proses litotektonik yang terjadi di Indonesia menyebabkan Pulau Sulawesi memiliki empat buah lengan dengan tektonika yang berbeda-beda membentuk satu kesatuan mozaik geologi. Berdasarkan pembagian struktur litotektonik Sulawesi, wilayah penelitian termasuk dalam zona Mandala Barat Bagian Utara (West and North Sulawesi Volcano-Plutonik Arc) yang secara umum didominasi oleh batuan gunung api berumur Eosen - Pliosen berselingan dengan batuan sedimen dan sebaliknya, serta sebagian batuan terobosan (Sompotan, 2012). Lebih lanjut menurut Sompotan (2012), pembentukan gunung api dan sedimen di daerah penelitian berlangsung relatif menerus sejak masa Eosen - Miosen Awal sampai Kuarter, dengan lingkungan laut dalam sampai daratan, atau merupakan suatu runtunan regresif. Pada batuan gunung api umumnya dijumpai selingan batuan sedimen dan sebaliknya, sehingga kedua batuan tersebut menunjukkan hubungan superposisi yang jelas. Satuan morfologi pegunungan umumnya dicirikan dengan bentuk alam yang menunjukkan bentuk puncak mengerucut dengan lereng relatif landai hingga terjal dengan ketinggian sampai 2.065 meter di atas permukaan laut (mdpl), yang didominasi oleh satuan batuan gunung api dan batuan sedimen berumur Tersier hingga Kuarter. Selain itu wilayah Kabupaten Gorontalo mempunyai topografi yang sebagian besar merupakan pesisir pantai di sebelah selatan berbatasan langsung dengan Teluk Tomini, dataran hingga pegunungan yang berada pada elevasi 0-2.065 mdpl. Secara fisiografis, Kabupaten Gorontalo dikelompokkan menjadi dua satuan wilayah morfologi, yaitu (1) satuan morfologi pesisir/laut berupa daerah pantai di sebelah selatan yang berbatasan langsung dengan Teluk Tomini; dan (2) satuan morfologi dataran berupa daerah dataran rendah yang berada di bagian tengah wilayah Cekungan Limboto yaitu di sekitar Danau Limboto. Pada umumnya, daerah ini terdiri dari satuan aluvium dan endapan danau. Aliran sungai di wilayah ini umumnya mempunyai pola sub-dendtritik dan sub-paralel.

Pembangunan berkelanjutan di Kabupaten Gorontalo memerlukan tidak saja data dan informasi tentang potensi kebencanaan, tetapi juga harus memperhatikan hubungan antara tingkat pengetahuan dan perekonomian masyarakatnya, serta faktor ketepatan rencana pembangunan. Demi kemajuan suatu daerah, perencanaan seharusnya tidak hanya fokus pada kebutuhan pembangunan, tetapi juga harus memperhatikan aspek kemungkinan bencana yang akan terjadi pada pembangunan tersebut. Pembangunan berkelanjutan adalah yang berlandaskan pada konsep manajemen bencana yaitu tahap pengurangan risiko (kesiapsiagaan, mitigasi, pencegahan) dan tahap pemulihan atau penanganan pasca bencana (tanggap darurat, pemulihan, pembangunan kembali). Pembangunan kembali (rehabilitasi dan rekonstruksi) yang lebih baik dan lebih aman (build back better) dari kondisi sebelum bencana haruslah juga dilaksanakan secara sistematis dengan pengaturan dan pengelolaan yang baik (Widjaja, 2014).

\section{Konteks PRB Banjir dalam Tujuan Pembangunan Berkelanjutan}

Kerangka Sendai untuk PRB telah memprioritaskan tata kelola risiko bencana untuk mengelola risiko bencana, khususnya secara substansial meningkatkan kerja sama internasional dengan negara-negara berkembang melalui dukungan yang memadai dan berkelanjutan untuk melengkapi tindakan secara nasional dalam pelaksanaan kerangka ini pada 2030 (United Nations, 2015a). Kebijakan ini diharapkan secara langsung dapat berkontribusi pada beberapa Tujuan Pembangunan Berkelanjutan (TPB) di Gorontalo, di antaranya:

a. TPB ke-1\&2: Pengentasan segala bentuk kemiskinan di semua tempat \& mengakhiri kelaparan, mencapai ketahanan pangan dan perbaikan nutrisi, serta menggalakkan pertanian yang berkelanjutan. Peristiwa banjir dapat berdampak pada kegagalan panen akibat terndamnya lahan pertanian. Dampak tersebut merupakan kerugian harta dan benda yang sangat besar bagi para petani. Selain berpotensi menyebabkan 
para petani menjadi miskin, hal ini juga akan mengurangi atau menghilangkan cadangan pangan di daerah yang terdampak bencana banjir. Mengingat hal tersebut maka diperlukan koordinasi dan kolaborasi publik seperti Dinas Sosial (Dinsos), Dinas Pertanian, Dinas Ketahanan Pangan hingga Kelompok Tani dapat secara bersama menjalankan rencana program mitigasi terjadinya bencana banjir yang dapat menghambat TPB tersebut. Perangkat daerah yang dimaksud bersama kelompok tani dapat merencanakan program bersama penyuluhan mengenai pentingnya konservasi lahan di daerah pertanian. Dalam penyuluhan dapat memberikan himbauan agar tidak menebang juga membakar pepohonan ketika akan membuka lahan. Selain itu diberikan pemahaman bahwa pepohonan tersebut memiliki fungsi untuk menyerap air hujan dan menjadikannya reservoir air tanah, selain itu akan menahan terjadinya aliran permukaan (runoff) yang dapat menggerus (erosi) tanah bagian atas (top soil) sehingga dapat terbawa ke saluran sungai, yang dengan seiring waktu dapat menjadi dangkal atau tersedimentasi. Program lainnya yang dapat dilakukan dalam koordinasi PRB yaitu memberikan bantuan pupuk sekaligus bibit pohon untuk ditanam bersama komoditi pertanian.

b. TPB-ke-3: Menjamin kehidupan yang sehat dan meningkatkan kesejahteraan seluruh penduduk seluruh usia. Banjir yang terjadi memiliki salahsatu dampak seperti gangguan psikologis dan kesehatan, seperti diare dan demam berdarah. Pengurangan risiko bencana yang terstruktur dan terkoordinasi dengan baik antara Badan Meteorologi, Klimatologi dan Geofisika (BMKG) dan Badan Penangulangan Bencana Daerah (BPBD) dalam peringatan dini serta kesiapsiagaan, serta Dinas Lingkungan Hidup \& Sumber Daya Alam (Dinas LH\&SDA), Dinas Kesehatan (Dinkes) dan sarana kesehatan yang tersedia dalam penanganan tanggap darurat, akan meminimalkan terjadinya risiko tersebut. Dengan demikian, koordinasi publik PRB dapat membantu mewujudkan tujuan TPB menjamin kesehatan dan kesejahteraan.

c. TPB ke-4: Memastikan pendidikan berkualitas bersifat inklusif dan adil, serta mempromosikan peluang pembelajaran seumur hidup untuk semua. Indonesia yang merupakan negara yang memiliki risiko bencana yang sangat tinggi, maka tentu kerentanan akan dampak dari bencana yang mungkin terjadi juga menjadi besar, termasuk pada sarana pendidikan, para pendidik dan peserta didik. Agar kerentanan tersebut dapat diminimalisir, maka tentu risikonya harus dapat dikurangi. Koordinasi publik PRB untuk mendukung terwujudnya TPB ke-4 ini dapat dilakukan dengan adanya kolaborasi antara Dinas Pendikan dan Kebudayaan (Dinas Dikbud), Perguruan Tinggi yang berada di wilayah tersebut serta Dinas Pekerjaan Umum dan Perencanaan Wilayah (Dinas PUPR). Dinas Dikbud dan Perguruan Tinggi dapat mendeseminasikan Satuan Pembelajaran Aman Bencana (SPAB) yang dikeluarkan oleh Kementerian Pendidikan Dan Kebudayaan dalam No. 33 Tahun 2019 Tentang Penyelenggaraan Program Satuan Pendidikan Aman Bencana) dari tingkatan dasar hingga Perguruan Tinggi. SPAB bisa dimasukkan dalam mata pelajaran olahraga, ekstrakurikuler dan mata kuliah pada perguruan tinggi, dimana guru dan dosen dapat memberikan pemahaman kepada murid atau mahasiswa untuk mengetahui penyebab banjir dan bagaimana mengurangi risiko dampaknya. Sedang Dinas PUPR dapat merencanakan tata ruang berbasis mitigasi dalam rencana pembangunan sarana dan fasilitas pendidikan pada daerah yang rawan hingga berisiko terdampak banjir serta bahaya alam lainnya.

d. TPB ke-8\&9: Mempromosikan pertumbuhan ekonomi yang berkelanjutan, inklusif dan berkelanjutan, pekerjaan layak dan produktif \& Membangun infrastruktur tangguh, mendorong industrialisasi yang inklusif dan berkelanjutan dan mendorong inovasi teknologi. Peristiwa banjir ataupun bencana alam lainnya memiliki dampak kerugian materi dan ekonomi hingga kerusakan infrastruktur dan lingkungan. 
Pembangunan infrastruktur yang tangguh melalui perencanaan tata ruang wilayah berbasis PRB dan pengembangan ekonomi masyarakat yang saling terkoordinasi dengan baik, antara Dinas PUPR, Dinsos, Dinas Perindustrian \& Perdagangan (Disperindag), serta Badan Penelitian dan Pengembangan (Balitbang), dapat dengan serta mewujudkan tercapainya TPB tersebut.

e. TPB ke-11: Membuat kota dan permukiman manusia inklusif, aman, tangguh dan berkelanjutan. Dengan koordinasi publik atau para pihak yang tersedia di daerah Gorontalo dalam manajemen pembangunan berbasis PRB, maka rencana kesiapsiagaan, ketanggapan darurat serta pembangunan yang lebih baik di masa depan, tentu akan mewujudkan daerah Gorontalo dan masyarakatnya inklusif berkelanjutan sesuai dengan tujuan TPB-ke 11.

Penyelenggaraan penataan ruang wilayah nasional harus dilakukan secara komprehensif, holistik, terkoordinasi, terpadu, efektif, dan efisien serta memperhatikan faktor politik, ekonomi, sosial, budaya, pertahanan, keamanan, dan kelestarian lingkungan hidup. Dalam perspektif pembangunan berkelanjutan, kooordinasi publik PRB dalam rencana kontinjensi (Rekon) di pemerintah daerah Kabupaten Gorontalo disarankan untuk melakukan penyusunan program pembangunan secara terukur dan spesifik sebelum terjadi kondisi darurat atau potensi bencana pada suatu wilayah, dengan berdasarkan analisis ancaman yang diperkirakan akan terjadi ataupun belum tentu terjadi (BNPB, 2008). Rekon tersebut termasuk dalam tahapan pra bencana, konsep kesiapsiagaan dan kedaruratan yang dilakukan secara berkoordinasi antarsektor (komunitas). Tahapan penyelenggaraan Rekon PRB dapat dilihat pada Gambar 3.

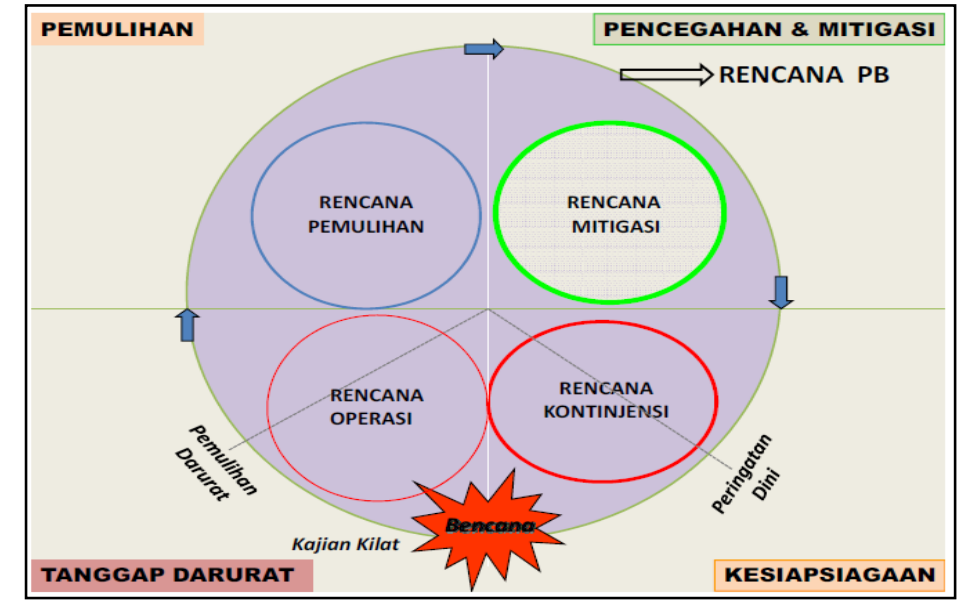

Sumber: BNPB, 2008

\section{Gambar 3. Tahapan Penyelenggaraan Penanggulangan Bencana}

Tahapan penyelenggaraan penanggulangan bencana tersebut terdiri dari koordinasi publik lintas sektor yang saling bekerja sama dengan peran dan fungsinya masing-masing, di antaranya instansi pemerintah dan masyarakat.

\section{Penilaian Bahaya dan Koordinasi Publik Untuk PRB}

Banjir merupakan salah satu bahaya dari fenomena meteorologi yang diawali dari hujan dengan intensitas tinggi dan/atau terus-menerus di daerah hulu atau di suatu wilayah sehingga menyebabkan debit aliran sungai menjadi lebih besar dari ambang normal 
(Paimin, Sukresno, dan Pramono, 2009). Bahaya banjir dapat berubah menjadi bencana jika suatu daerah memiliki bentang lahan yang tata guna lahannya sudah tidak sesuai lagi dengan fungsinya (Halim, 2014). Selain itu faktor kemiringan lereng dan jenis tanah yang ada di daerah hulu juga mempunyai peran penting dalam mengalirkan air hujan sebagai aliran larian (runoff), sehingga pada daerah yang bertopografi landai akan menjadi wilayah yang sangat berpotensi mengalami genangan atau banjir (Aji, Sudarsono, dan Sasmito, 2014). Hal ini sesuai dengan UU No. 24 Tahun 2007 tentang Penanggulangan Bencana mendefinisikan banjir sebagai salah satu peristiwa atau keadaan terendamnya suatu daerah atau daratan karena volume air yang meningkat. Dampak dari peristiwa ini pula sangat terkait dengan pengaruh kegiatan manusia (antropogenik) dan beberapa faktor lainnya seperti intensitas hujan yang tinggi, kondisi sungai dan daerah hulu yang rusak, kondisi budidaya/alih fungsi lahan yang tidak sesuai, serta pasang surut air laut (BNPB, 2008).

Parameter-parameter yang menjadi penentu zona risiko banjir di wilayah penelitian mengikuti Peraturan Menteri Kehutanan Republik Indonesia No. 32 Tahun 2009 tentang Tata Cara Penyusunan Rencana Teknik Rehabilitasi Hutan dan Lahan DAS (RTRHL-DAS). Karakteristik yang dikaji berupa bentang lahan dan tata gunanya, kelerengan, jenis tanah, topografi serta rerata curah hujan yang diolah secara geospasial sehingga menghasilkan informasi zona risiko bahaya banjir (Gambar 4).

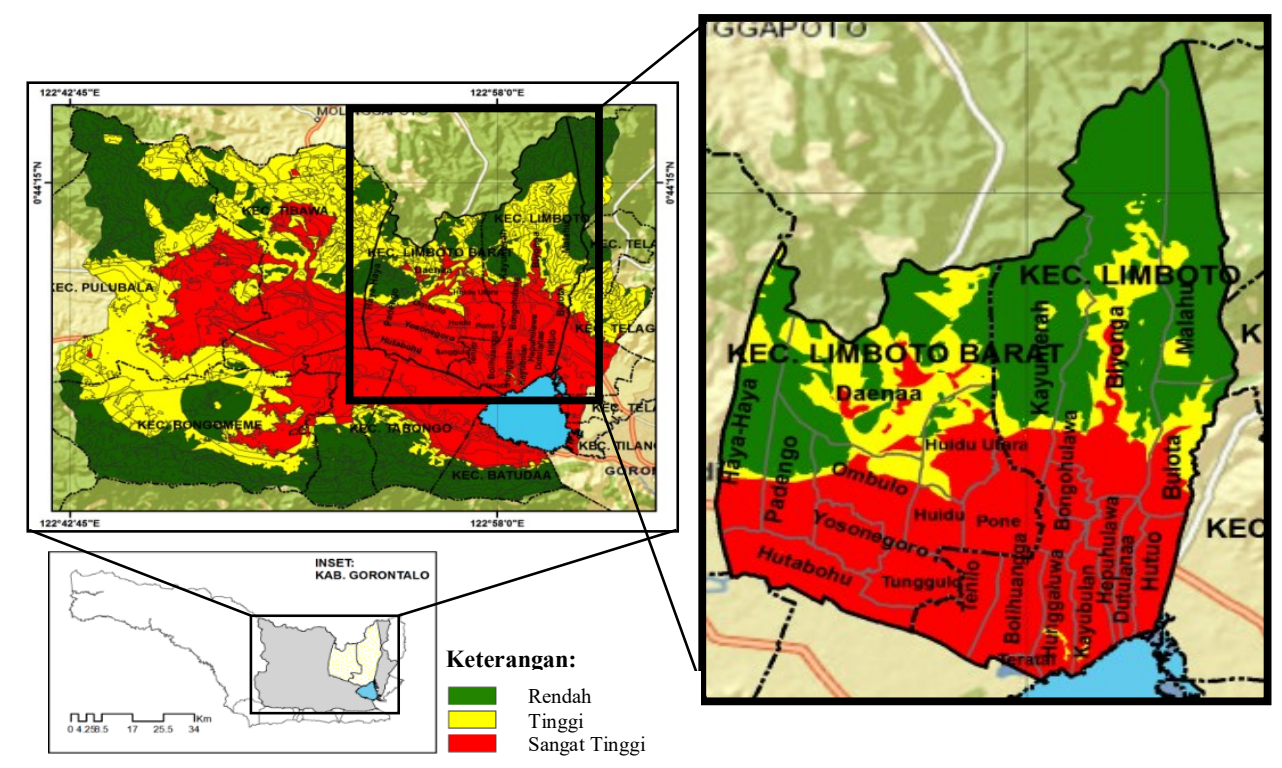

Sumber: Analisis Penulis, 2018

Gambar 4. Zona Risiko Bahaya Banjir Pada Cakupan DAS Limboto

Hasil penilaian risiko banjir berdasarkan analisis geospasial menurut karakteristik DAS Limboto di atas dapat diketahui bahwa beberapa daerah yang termasuk dalam cakupan DAS tersebut merupakan daerah dengan tingkat risiko rendah, tinggi sampai sangat tinggi. Sebagian besar daerah yang memiliki tingkat risiko banjir tinggi dan sangat tinggi merupakan daerah dengan bentang lahan dataran aluvial dan bertopografi rendah, sedangkan wilayah perbukitan di sebelah utara daerah penelitian masih masuk pada zona aman atau berisiko rendah. Adapun beberapa daerah yang termasuk pada zona risiko tinggi hingga sangat tinggi di antaranya adalah Desa Haya-Haya bagian selatan, Desa Padengo, Desa Daenaa, Desa Ombulo, Desa Yosonegoro, Desa Hutabohu, Desa Tunggulo, Desa 
Pone, Desa Huidu dan Huidu Utara (Kecamatan Limboto Barat); Desa Biyonga, Desa Bulota, Desa Hutuo, Desa Dutulanaa, Desa Hepuhulawa, Desa Kayubulan, Desa Teratai, Desa Hunggaluwa, Desa Bolihuangga, Desa Tenilo, dan Desa Bongohulawa (Kecamatan Limboto).

Penilaian bahaya secara geospasial pada wilayah penelitian menunjukkan bahwa sebagian besar cakupan DAS Limboto termasuk daerah ibukota Kabupaten Gorontalo berpotensi mengalami bencana banjir yang dapat menghambat pelaksanaan pembangunan berkelanjutan. Untuk mengurangi risiko bencana yang berpotensi akan terjadi, maka dibutuhkan koordinasi antarsektor dari sumber daya publik yang tersedia di Kabupaten Gorontalo. Sumber daya publik yang berhasil diinventarisasi pada wilayah Kabupaten Gorontalo terbagi dua yaitu instansi pemerintah dan potensi masyarakat, dan masingmasing akan saling berkoordinasi dan bekerja sama dalam penyelenggaraan PRB banjir dengan menyesuaikan kriteria (Vidiarina, 2010). Sumber daya publik yang akan saling berkoordinasi untuk mendukung PRB banjir ditampilkan pada Tabel 1.

Tabel 1. Koordinasi Publik PRB Banjir di Kabupaten Gorontalo

\begin{tabular}{|c|c|c|}
\hline Tahap & Instansi/Sektor & Tugas/Wewenang \\
\hline \multirow[t]{6}{*}{$\begin{array}{c}\text { Sebelum (Pra) } \\
\text { Bencana }\end{array}$} & $\begin{array}{l}\text { 1. Sektor Pemerintahan (Badan } \\
\text { Perencanaan dan Pengembangan } \\
\text { Daerah/Bappeda) }\end{array}$ & $\begin{array}{l}\text { 1. Melakukan pembinaan pembangunan } \\
\text { daerah berdasarkan hasil riset dan } \\
\text { kebijakan (Research and Development). }\end{array}$ \\
\hline & $\begin{array}{l}\text { 2. Sektor Pekerjaan Umum (Dinas } \\
\text { Pekerjaan Umum dan Penataan } \\
\text { Ruang/DisPUPR, Dinas Perumahan } \\
\text { dan Kawasan } \\
\text { Permukiman/DisPerkim, Dinas } \\
\text { Pemberdayaan Masyarakat dan } \\
\text { Desa/DisPemdes, Badan } \\
\text { Penanggulangan Bencana } \\
\text { Daerah/BPBD) }\end{array}$ & $\begin{array}{l}\text { 2. Merencanakan tata ruang dan bangunan } \\
\text { yang aman dari banjir, penentuan jalur } \\
\text { evakuasi atau lokasi pengungsian. }\end{array}$ \\
\hline & $\begin{array}{l}\text { 3. Sektor Perhubungan (Badan } \\
\text { Meteorologi, Klimatologi dan } \\
\text { Geofisika/BMKG, BPBD) }\end{array}$ & $\begin{array}{l}\text { 3. Melakukan deteksi mengenai prakiraan } \\
\text { terjadinya cuaca hujan ekstrim dan } \\
\text { peringatan dini untuk kesiapsiagaan } \\
\text { pemerintah dan masyarakat. }\end{array}$ \\
\hline & $\begin{array}{l}\text { 4. Sektor Energi dan Sumber Daya } \\
\text { Mineral (Dinas Lingkungan Hidup } \\
\text { dan Sumber Daya Alam/DLHSDA) }\end{array}$ & $\begin{array}{l}\text { 4. Merencanakan upaya mitigasi banjir } \\
\text { seperti reboisasi hutan daerah hulu, } \\
\text { inisiasi kegiatan kerja bakti } \\
\text { pembersihan, pembagian bibit, dan } \\
\text { sebagainya. }\end{array}$ \\
\hline & 5. Sektor Keuangan (Badan Keuangan) & $\begin{array}{l}\text { 5. Menyiapkan anggaran biaya kegiatan } \\
\text { penyelenggaraan penanggulangan } \\
\text { bencana pada masa pra bencana, } \\
\text { termasuk dana taktis untuk tanggap } \\
\text { darurat dan rehabilitasi. }\end{array}$ \\
\hline & $\begin{array}{l}\text { 6. Sektor Lingkungan Hidup } \\
\text { (DLHSDA, BPBD, Dinas Pertanian; } \\
\text { Dinas Ketahanan Pangan, Dinsos) }\end{array}$ & $\begin{array}{l}\text { 6. Merencanakan dan mengendalikan } \\
\text { upaya yang bersifat preventif dan } \\
\text { advokasi dalam pencegahan bencana } \\
\text { b. Menginisiasi kegiatan penanaman } \\
\text { pohon, kerja bakti pembersihan } \\
\text { sungai dan lingkungan masyarakat, } \\
\text { dan sebagainya. }\end{array}$ \\
\hline
\end{tabular}




\section{Lanjutan Tabel 1}

\begin{tabular}{|c|c|c|}
\hline Tahap & Instansi/Sektor & $\begin{array}{c}\text { Tugas/Wewenang } \\
\end{array}$ \\
\hline & $\begin{array}{l}\text { 7. Sektor Lembaga Penelitian dan } \\
\text { Pendidikan Tinggi (Balitbang, } \\
\text { BPBD) }\end{array}$ & $\begin{array}{l}\text { 7. a. Melakukan penilaian dan analisis } \\
\text { risiko bencana; } \\
\text { b. Menciptakan teknologi dan/atau } \\
\text { material pendukung PRB; } \\
\text { c. Menyebarkan informasi kebencanaan } \\
\text { seperti infografis dan peta bencana; } \\
\text { dan } \\
\text { d. Menciptakan teknologi peringatan } \\
\text { dini. }\end{array}$ \\
\hline & $\begin{array}{l}\text { 8. Perguruan Tinggi (Univ. } \\
\text { Muhammadiyah Gorontalo/UMGo, } \\
\text { Univ. Gorontalo/UG, Institut Agama } \\
\text { Islam Negeri/IAIN-Sultan Amai, } \\
\text { Univ. Nadhlatul Ulama/UNU,) }\end{array}$ & $\begin{array}{l}\text { 8. a. Melakukan penilaian dan analisis } \\
\text { risiko bencana; } \\
\text { b. Menciptakan teknologi dan/atau } \\
\text { material pendukung PRB; } \\
\text { c. Menyebarkan informasi kebencanaan } \\
\text { seperti infografis dan peta bencana; } \\
\text { dan } \\
\text { d. Menciptakan teknologi peringatan } \\
\text { dini. }\end{array}$ \\
\hline & $\begin{array}{l}\text { 9. Kelompok Masyarakat (Forum } \\
\text { Relawan-Desa Tangguh } \\
\text { Bencana/FR-Destana, LSM } \\
\text { Kambungu Beresi) }\end{array}$ & $\begin{array}{l}\text { 9. Mengurangi dan menangani risiko banjir } \\
\text { dengan edukasi dini di tingkat keluarga } \\
\text { hingga kearifan lokal. }\end{array}$ \\
\hline & $\begin{array}{l}\text { 10. Media (Radar Gorontalo, Gorontalo } \\
\text { Post, Hulandalo.id, Kronologi.id, } \\
\text { dan sebagainya) }\end{array}$ & $\begin{array}{l}\text { 10. Membentuk opini publik dalam hal } \\
\text { membangun ketahanan masyarakat } \\
\text { menghadapi bencana banjir melalui } \\
\text { kecepatan dan ketepatan dalam } \\
\text { memberikan informasi kebencanaan } \\
\text { berupa peringatan dini, kejadian bencana } \\
\text { serta upaya penanggulangannya, serta } \\
\text { pendidikan kebencanaan kepada } \\
\text { masyarakat. }\end{array}$ \\
\hline & $\begin{array}{l}\text { 11. Swasta, Lembaga Nonpemerintah, } \\
\text { Lembaga Internasional (Komunitas } \\
\text { Peduli, Filantropi, dan sebagainya) }\end{array}$ & $\begin{array}{l}\text { 11. Memberikan asuransi dan/atau beasiswa } \\
\text { sebagai bentuk risk transfer }\end{array}$ \\
\hline & $\begin{array}{l}\text { 12. Sektor Pendidikan (Dinas } \\
\text { Pendidikan dan Kebudayaan) }\end{array}$ & $\begin{array}{l}\text { 12. Memberikan pelatihan dan edukasi dini } \\
\text { di tingkat sekolah mengenai } \\
\text { kebencanaan melalui kurikulum sesuai } \\
\text { Satuan Pembelajaran Aman Bencana } \\
\text { (SPAB) yang diperuntukkan untuk guru } \\
\text { dan siswa }\end{array}$ \\
\hline \multirow[t]{2}{*}{ Saat Bencana } & $\begin{array}{l}\text { 1. Sektor Kesehatan (Dinas } \\
\text { Kesehatan/Dinkes, Sarana } \\
\text { Kesehatan: Rumah Sakit Dunda, } \\
\text { Puskemas/Pustu, Palang Merah } \\
\text { Indonesia/PMI, dan sebagainya) }\end{array}$ & $\begin{array}{l}\text { 1. Memberikan pelayanan kesehatan dan } \\
\text { medik termasuk obat-obatan dan } \\
\text { paramedis }\end{array}$ \\
\hline & $\begin{array}{l}\text { 2. Sektor Sosial (Dinsos-Taruna Siaga } \\
\text { Bencana/Tagana, Satuan Polisi } \\
\text { Pamong Praja/Satpol PP, BPBD, } \\
\text { Badan SAR Nasional/Basarnas) }\end{array}$ & $\begin{array}{l}\text { 2. a. Merencanakan kebutuhan pangan, } \\
\text { sandang, dan kebutuhan dasar } \\
\text { lainnya untuk para pengungsi; dan }\end{array}$ \\
\hline
\end{tabular}




\begin{tabular}{|c|c|c|}
\hline Tahap & Instansi/Sektor & Tugas/Wewenang \\
\hline & & $\begin{array}{l}\text { b. Tanggap darurat, pencarian dan } \\
\text { penyelamatan, pengamanan aset, } \\
\text { penyaluran bantuan logistik termasuk } \\
\text { air bersih, penyediaan lokasi } \\
\text { pengungsian dan dapur umum. }\end{array}$ \\
\hline & $\begin{array}{l}\text { 3. Sektor Pekerjaan Umum (Dinas } \\
\text { PUPR) }\end{array}$ & $\begin{array}{l}\text { 3. Menyediakan lokasi evakuasi dan sarana } \\
\text { prasarana lokasi pengungsian, shelter, } \\
\text { sekolah darurat, bantuan alat berat, dan } \\
\text { sebagainya. }\end{array}$ \\
\hline & $\begin{array}{l}\text { 4. Sektor Perhubungan \& Komunikasi } \\
\text { (Dinas Perhubungan/Dishub, Dinas } \\
\text { Komunikasi dan } \\
\text { Informasi/Diskominfo) }\end{array}$ & $\begin{array}{l}\text { 4. Merencanakan kebutuhan transportasi } \\
\text { dan komunikasi kedaruratan untuk } \\
\text { kepentingan bencana. }\end{array}$ \\
\hline & $\begin{array}{l}\text { 5. Sektor Tenaga Kerja dan } \\
\text { Transmigrasi (Dinas Tenaga Kerja } \\
\text { dan ransmigrasi/Disnakertrans, } \\
\text { Satpol PP, BPBD) }\end{array}$ & $\begin{array}{l}\text { 5. Merencanakan pengerahan dan } \\
\text { pemindahan korban bencana ke daerah } \\
\text { yang aman (evakuasi). }\end{array}$ \\
\hline & $\begin{array}{l}\text { 6. TNI/POLRI (Satuan TNI dan } \\
\text { POLRI) }\end{array}$ & $\begin{array}{l}\text { 6. Membantu dalam kegiatan SAR, dan } \\
\text { pengamanan saat darurat termasuk } \\
\text { mengamankan lokasi yang ditinggalkan } \\
\text { karena penghuninya mengungsi. }\end{array}$ \\
\hline & $\begin{array}{l}\text { 7. Masyarakat (Pemerintah Kecamatan } \\
\text { dan Desa, FR Destana, Tim Relawan } \\
\text { umum) }\end{array}$ & $\begin{array}{l}\text { 7. Menangani pencarian dan penyelamatan } \\
\text { secara mandiri sambil menunggu } \\
\text { bantuan tiba, atau bersama tim. }\end{array}$ \\
\hline & $\begin{array}{l}\text { 8. Swasta dan Lembaga } \\
\text { Nonpemerintah }\end{array}$ & $\begin{array}{l}\text { 8. Memberikan bantuan dan keperluan } \\
\text { darurat. }\end{array}$ \\
\hline & $\begin{array}{l}\text { 9. Perguruan Tinggi (UMGo, UG, } \\
\text { IAIN, UNU) }\end{array}$ & $\begin{array}{l}\text { 9. Memberikan bantuan tenaga medis dan } \\
\text { kebutuhan darurat pengungsi. }\end{array}$ \\
\hline & $\begin{array}{l}\text { 10. Media (Radar Gorontalo, Gorontalo } \\
\text { Post, Hulandalo.id, Kronologi.id, } \\
\text { dan sebagainya) }\end{array}$ & $\begin{array}{l}\text { 10. Memberikan informasi terkini dan } \\
\text { akurat mengenai keadaan dan kebutuhan } \\
\text { bencana yang terjadi. }\end{array}$ \\
\hline \multirow[t]{5}{*}{$\begin{array}{l}\text { Setelah } \\
\text { (Pasca) } \\
\text { Bencana }\end{array}$} & $\begin{array}{l}\text { 1. Sektor Kesehatan (Dinkes dan RS } \\
\text { Dunda, PMI) }\end{array}$ & $\begin{array}{l}\text { 1. Memberikan pelayanan kesehatan dan } \\
\text { medis termasuk obat-obatan dan para } \\
\text { medis, juga trauma healing. }\end{array}$ \\
\hline & $\begin{array}{l}\text { 2. Sektor Sosial (Dinsos-Tagana, } \\
\text { Satpol PP, BPBD) }\end{array}$ & $\begin{array}{l}\text { 2. Merencanakan kebutuhan pangan, } \\
\text { sandang, dan kebutuhan dasar lainnya } \\
\text { untuk para pengungsi. }\end{array}$ \\
\hline & $\begin{array}{l}\text { 3. Sektor Pekerjaan Umum (PUPR, } \\
\text { DisPerkim) }\end{array}$ & $\begin{array}{l}\text { 3. Memenuhi kebutuhan pemulihan sarana } \\
\text { dan prasarana seperti shelter pengungsi, } \\
\text { rumah/hunian (huntara) dan sekolah } \\
\text { sementara. }\end{array}$ \\
\hline & $\begin{array}{l}\text { 4. Sektor Perhubungan \& Komunikasi } \\
\text { (Dishub, Diskominfo) }\end{array}$ & $\begin{array}{l}\text { 4. Memenuhi kebutuhan transportasi dan } \\
\text { komunikasi. }\end{array}$ \\
\hline & $\begin{array}{l}\text { 5. Sektor Tenaga Kerja dan } \\
\text { Transmigrasi (Disnakertrans, Satpol } \\
\text { PP, BPBD) }\end{array}$ & $\begin{array}{l}\text { 5. Merencanakan pengerahan dan } \\
\text { pemindahan korban bencana ke daerah } \\
\text { yang aman bencana. }\end{array}$ \\
\hline
\end{tabular}


Lanjutan Tabel 1

\begin{tabular}{cll}
\hline Tahap & \multicolumn{1}{c}{ Instansi/Sektor } & \multicolumn{1}{c}{ Tugas/Wewenang } \\
\hline 6. $\begin{array}{l}\text { Swasta, Lembaga Nonpemerintah, } \\
\text { Lembaga Internasional (Komunitas } \\
\text { Peduli, Filantropi, dan sebagainya) }\end{array}$ & $\begin{array}{l}\text { 6. } \begin{array}{l}\text { Memberikan bantuan dan keperluan } \\
\text { tambahan untuk masyarakat terdampak } \\
\text { bencana dengan berkoordinasi dengan } \\
\text { pemerintah daerah, asuransi kesehatan } \\
\text { dan harta benda, beasiswa pendidikan, } \\
\text { dan sebagainya. }\end{array} \\
\end{array}$ & $\begin{array}{ll}\text { Memberikan bantuan tenaga medis dan } \\
\text { pendidikan lanjutan pasca bencana. }\end{array}$ \\
& $\begin{array}{l}\text { Perguruan Tinggi (UMGo, UG, } \\
\text { IAIN, UNU) } \\
\text { 8. Media (Radar Gorontalo, Gorontalo } \\
\text { Post, Hulandalo.id, Kronologi.id, } \\
\text { dan sebagainya) }\end{array}$ & $\begin{array}{l}\text { 8emberikan informasi terkini dan } \\
\text { akurat mengenai keadaan dan kebutuhan } \\
\text { pasca bencana }\end{array}$ \\
\hline
\end{tabular}

Sumber: Hasil Inventarisasi Sumber Daya Publik/Komunitas, 2018

\section{Kesimpulan}

Pada hasil penyusunan skema koordinasi publik untuk PRB banjir di wilayah penelitian dapat diketahui bahwa sumber daya instansi pemerintah dan potensi masyarakat akan lebih banyak berperan untuk bekerja sama pada kegiatan tahap pra bencana (pencegahan, mitigasi dan kesiapsiagaan) dan tahap saat bencana (tanggap darurat). Hal ini mengindikasikan bahwa tahap-tahap tersebut merupakan kegiatan PRB yang harus lebih diperhatikan oleh Pemerintah Kabupaten Gorontalo dalam rangka merencanakan pembangunan berkelanjutan di daerahnya. Menurut Maarif (2013), kegiatan PRB harus menjadi upaya bersama di tingkat nasional maupun lokal, sebagai sebuah investasi strategis dalam pembangunan berkelanjutan, mengingat dampak kerugian yang diakibatkan oleh kejadian bencana selalu lebih besar dari anggaran penanggulangannya dari pemerintah.

Dengan demikian, koordinasi publik antara sumber daya instansi pemerintah dan potensi masyarakat secara bersama pada kegiatan PRB akan menjadi investasi strategis pada pembangunan berkelanjutan di Kabupaten Gorontalo. Hal ini juga menunjukkan paradigma kebencanaan responsif yang telah lama kita adaptasikan, yaitu masyarakat selalu menjadi objek bencana, sudah harus berubah menjadi paradigma adaptif, yaitu seluruh elemen yang meliputi pemerintah, perguruan tinggi serta masyarakat memiliki peran utama (subjektif) dalam menghadapi risiko bencana. Salah satunya seperti koordinasi antara Dinas Pekerjaan Umum dan Penataan Ruang (PUPR), Perguruan Tinggi dan Forum Desa Tangguh Bencana dalam merencanakan tata ruang wilayah berbasis kajian risiko bencana. Oleh karena itu, Pemerintah Kabupaten Gorontalo perlu memperhatikan koordinasi publik PRB sebagai sebuah dokumen Rencana Kontinjensi yang dimaklumatkan dalam peraturan daerah. Adanya pembagian tugas kelompok kerja penanggulangan bencana (Pokja PB) untuk pencegahan (prevention), mitigasi (mitigation), kesiapsiagaan (preparedness), tanggap darurat (emergency respons) hingga proses rehabilitasi (recovery) yang saling bersinergi dengan sendirinya akan mendukung Rencana Pelaksanaan Pembangunan Berkelanjutan di Kabupaten Gorontalo. Selain itu, melalui penelitian ini akan mencoba untuk menginisiasi terbitnya Kebijakan Pemerintah Daerah/Peraturan Bupati Tentang Kelompok Kerja (Pokja) Pembangunan Berkelanjutan Berbasis Pengurangan Risiko Bencana. 


\section{Ucapan Terima Kasih}

Ucapan terima kasih penulis ucapkan kepada Kementerian Riset, Teknologi dan Pendidikan Tinggi (Kemenristekdikti) Republik Indonesia, atas hibah Penelitian Dosen Pemula (PDP) tahun anggaran 2018 berdasarkan Surat Keputusan Nomor 18/M/KP.KPT/2018 dan Perjanjian/Kontrak Nomor 1120/K9/KT.03/2018 sehingga penelitian ini dapat terselenggara.

\section{Daftar Pustaka}

Ahdi, D. (2015). Perencanaan penanggulangan bencana melalui pendekatan manajemen risiko. Reformasi, 5(1), 13-30. Retrieved from https://jurnal.unitri.ac.id/index.php/reformasi/article/view/60.

Aji, M. D., Sudarsono, B., dan Sasmito, B. (2014). Identifikasi zona rawan banjir menggunakan sistem informasi geografis (studi kasus: Sub DAS Dengkeng). Jurnal Geodesi Undip, 3(1), 36-50. Retrieved from https://ejournal3.undip.ac.id/index.php/geodesi/article/view/4708.

Ake, U. R., Koto, A. G., dan Taslim, I. (2018). Analisis kesesuaian penggunaan lahan berdasarkan arahan fungsi kawasan di Daerah Aliran Sungai (DAS) Alo Kabupaten Gorontalo. Jurnal Sains Informasi Geografi, 1(1), 41-50. doi:10.31314/jsig.v1i1.118.

Anam, K., Mutholib, A., Setiyawan, F., Andini, B. A., dan Sefniwati, S. (2018). Kesiapan institusi lokal dalam menghadapi bencana tsunami: Studi kasus Kelurahan Air Manis dan Kelurahan Purus, Kota Padang. Jurnal Wilayah dan Lingkungan, 6(1), 15-29. doi:10.14710/jwl.6.1.15-29.

Apandi, T., dan Bachri, S. (1997). Peta geologi lembar Kotamobagu, Sulawesi skala 1:250.000. Bandung: Pusat Penelitian dan Pengembangan Geologi (P3G).

Azhar, R. A. (2016). Banjir bandang meluas hingga sembilan kecamatan. Retrieved June 25, 2018, from https://regional.kompas.com/read/2016/10/26/18122711/banjir.bandang.di.gorontalo.meluas.hingga. sembilan.kecamatan.

Badan Koordinasi Nasional Penanggulangan Bencana dan Penanganan Pengungsi (Bakornas PBP). (2002). Arahan mitigasi bencana perkotaan di Indonesia. Jakarta: Sekretariat Badan Koordinasi Nasional Penanggulangan Bencana dan Penanganan Pengungsi.

Badan Nasional Penanggulangan Bencana (BNPB). (2008). Peraturan Kepala Badan Nasional Penanggulangan Bencana Nomor 4 Tahun 2008. Jakarta: Badan Nasional Penanggulangan Bencana.

Badan Nasional Penanggulangan Bencana (BNPB). (2018). Data informasi bencana Indonesia. Retrieved August 11, 2018, from http://dibi.bnpb.go.id/dibi/.

Dewan, A. M. (2013). Hazards, risk, and vulnerability. In Flood in a Megacity: Geospatial techniques in assessing hazards, risk and vulnerability (1st ed.). Dordrecht, Netherlands: Springer Science dan Business Media. doi:10.1007/978-94-007-5875-9_2.

Eddy, T. (2015). Kajian lingkungan hidup strategis dalam perencanaan wilayah dan tata ruang. Fakultas Teknik Universitas Pembangunan Panca Budi, Medan. ISBN: 978-602-0903-06-4.

Faturahman, B. M. (2018). Konseptualisasi mitigasi bencana melalui perspektif kebijakan publik. PUBLISIA: Jurnal Ilmu Administrasi Publik, 3(2), 122-134. Retrieved from http://jurnal.unmer.ac.id/index.php/jkpp/article/view/2365.

Halim, F. (2014). Pengaruh hubungan tata guna lahan dengan debit banjir pada Daerah Aliran Sungai Malalayang. Jurnal Ilmiah Media Engineering, 4(1), 45-54. Retrieved from https://ejournal.unsrat.ac.id/index.php/jime/article/view/4461.

Hidayah, K. (2015). Kebijakan penanggulangan bencana di era otonomi daerah (kajian terhadap penanganan kasus luapan lumpur Lapindo Brantas). Jurnal Borneo Administrator, 11(3), 298-315. doi:10.24258/jba.v11i3.204.

Idris, S. R., dan Pramudito, H. (2018). Mencermati keunikan bencana geologi di Indonesia. In Prosiding Pertemuan Ilmiah Tahunan (PIT) Ke-5 Riset Kebencanaan Ikatan Ahli Kebencanaan Indonesia (IABI) Universitas Andalas (pp. 437-443). Padang: Universitas Andalas.

Maarif, S. (2013). Pengurangan risiko bencana investasi untuk ketangguhan bangsa. Mataram: Badan Nasional Penanggulangan Bencana. Retrieved from https://www.bnpb.go.id/pengurangan-risiko-bencana- 


\section{Koordinasi Publik untuk Pengurangan Risiko Bencana Banjir ...}

investasi-untuk-ketangguhan-bangsa.

Paimin, P., Sukresno, S., dan Pramono, I. B. (2009). Teknik mitigasi banjir dan tanah longsor. (A. N. Ginting, Ed.). Balikpapan: Tropenbos International Indonesia Programme.

Pemerintah Kabupaten Gorontalo. (2013). Peta daerah aliran sungai Limboto.

Probosiwi, R. (2015). Peran pemerintah lokal dalam menghadapi bencana tsunami di Pacitan Jawa Timur. Jurnal Widyariset LIPI, 18(2), 1-22.

Sompotan, A. F. (2012). Struktur geologi Sulawesi. Bandung: Perpustakaan Sains Kebumian. Institut Teknologi Bandung.

Suryani, A. S. (2016). Antisipasi bencana hidrometeorologi di Indonesia. Majalah Info Singkat Kesejahteraan Sosial, $\quad 8(12), \quad 9-12 . \quad$ Retrieved from https://www.academia.edu/28294722/12_Antisipasi_Bencana_Hidrometeorologi_di_Indonesia.

Taslim, I., Koto, A. G., dan Tisen, T. (2017). Studi geomorfologi kebencanaan berbasis analisis spasial untuk pembangunan berkelanjutan. Jurnal MIPA Tadulako, 72), 3-8. doi:10.17605/OSF.IO/8Z56X.

United Nations. (2015a). Sendai framework for disaster risk reduction 2015-2030. Geneva. Retrieved from https://www.preventionweb.net/files/43291_sendaiframeworkfordrren.pdf.

United Nations. (2015b). Transforming our world: the 2030 agenda for sustainable development. Retrieved from https://sustainabledevelopment.un.org/post2015/transformingourworld.

Vidiarina, H. D. (2010). Perencanaan kontinjensi: Tinjauan tentang beberapa pedoman perencanaan dan rencana kontinjensi. Indonesia.

Wibowo, M. (2018). Kajian dampak rencana pembangunan Kawasan Wisata Marina di Pesisir Kabupaten Belitung terhadap kualitas lingkungan sekitarnya. Jurnal Presipitasi: Media Komunikasi Dan Pengembangan Teknik Lingkungan, 15(1), 11-24.

Widjaja, B. W. (2014, September). Bekerja dengan hati untuk hasil masterpiece. Gema BNPB: Ketangguhan Bangsa Dalam Menghadapi Bencana, 61-70. Retrieved from https://bnpb.go.id/uploads/publication/1092/Gema SEP 2014.pdf.

Yumantoko, Y. (2019). Kolaborasi para pihak dalam penanganan destinasi wisata terdampak bencana di Taman Nasional Gunung Rinjani. Jurnal Penelitian Kehutanan, 3(1), 15-28. 